\title{
O SISTEMA NACIONAL DE AVALIAÇÃO DA
EDUCAÇÃO BÁSICA
}

MARIA INÊS GOMES DESÁ PESTANA*

Gostaria de agradecer e comunicar-lhes a minha certeza de que os nossos trabalhos neste Seminário serão muito profícuos e que continuaremos a caminhar para implantar este Sistema de Avaliaçảo e contribuir, desta forma, para a melhoria do sistema educacional brasileiro.

Inicio falando um pouco sobre o SAEB - Sistema Nacional de Avaliaçăo da Educaçăo Básica. Seu desenvolvimento foi objeto de um convênio firmado entre a SENEB e o IICA - Instituto Interamericano de Cooperação para a Agricultura, da OEA. O projeto foi montado para avaliar o Projeto Nordeste, um acordo de empréstimo que vinha sendo negociado com o Banco Mundial. Como a proposta de avalição era muito abrangente houve decisão da SENEB de realizar o estudo no Brasil inteiro. Assim, naquele ano de 1988, uma equipe da SENEB, com o apoio do ICA, a cooperação e a consultoria do Professor Júlio Jacobo e outros, desenvolveu a metodologia de avaliação que, por meio de um levantamento de dados, permitiria atingir dois objetivos:

Primeiramente, o de buscar qualificar os resultados que o sistema educacional vem obtendo e, com isto, tornando mais claros estes resultados, eviden-

- Gerente de Avaliaģáo do Instituto Nacional de Estodos e Pesquisas Ecucacionals - INEPAMEC 
ciar o desempenho da escola pública no Brasil, já que, na primeira aplicação do Sistema, foram realizados levantamentos apenas em escolas públicas de $1^{\mathfrak{Q}}$ grau, das redes estadual e municipal.

O segundo objetivo era criar e consolidar competências, em todos os estados brasileiros, para tratar de questōes relacionadas à avaliaçăo do sistema educacional. Trata-se, portanto, de um sistema baseado na existência e funcionamento de equipes do MECe das secretarias estaduais de educação.

Nosso interesse era fazer com que as administraçöes estaduais se voltassem para trabalhar com o tema da avaliação, realizando levantamentos e estudos, utilizando os seus resultados e, desta maneira, sendo levados à reflexāo sobre a questão da qualidade dos resultados e sobre a atuaçăo das administraçöes estaduais e municipais de educaçăo.

OSistema está concebido em dois níveis: o primeiro refere-se a indicadores que permitem a análise do sistema educacional como um todo. Esse indicadores săo, basicamente, de produtividade e eficiência do sistema educacional. A Coordenadoria de Planejamento Setorial-CPS, do MEC, adaptou um modelo da UNESCO de estudo de flụxo e de produtividade. Este modelo aplicado dá uma noção das taxas de produtividade do sistema, das perdas com evasăo e com repetência, dos níveis de escolarizaçáo real em cada um dos estados e no país. Este é o primeiro nível de aproximação da realidade do sistema educacional.

O segundo nivel proposto no Sistema de Avaliação refere-se às condições de trabalho e às questóes da escola. No primeiro levantamento de dados, realizado em 1990, foram aplicados diversos instrumentos em cerca de 6.000 escolas que compuseram a amostra. Um primeiro instrumento buscou levantar questőes relativas à gestão escolar, respondidas por cerca de 3.000 diretores de escola; um outro instrumento foi respondido por cerca de 27.000 professores, e buscava conhecer o trabalho realizado em sala de aula e também o pensamento dos professores acerca do seu próprio trabalho, das formas de organização e dos objetivos dos trabalhos docentes. Além disto, também foi feito um levantamento dos custos reais da escola para funcionar, isto é, qual o custo efetivo do aluno. Por fim, foram aplicados os testes de rendimento elaborados pela Fundação Carlos Chagas, nas primeiras, terceiras, quintas e sétimas séries, que foram respondidos por aproximadamente 110.000 alunos.

A nossa intenção, com a metodologia utilizada, é estudar as correlações entre questões relativas à gestão escolar, competência docente, custos e o rendimento do aluno. $\mathrm{O}$ rendimento do aluno é,'pois, contraponto deste sistema. Pretendemos saber quais são os fatores que afetam o rendimento do aluno, hoje, na realidade da escola brasileira. Isto é possível devido ao método de construção da amostra - amostras relacionadas -, onde selecionam-se uma escola, turmas, alunos desses professores, que, incluindo-se o diretor da escola, respondem aos instrumentos específicos. 
A partir daí, procura-se definir correlações entre variáveis da realidade da escola (que compõem as áreas de estudo) e em que medida estas afetam o rendimento do aluno (este é o trabalho que atualmente está sendo desenvolvido) para, assim, chegar a indicaç̋es mais concretas sobre e para a atuaçăo dos administradores e demais agentes educacionais, desde o MEC até a escola.

A realizaçåo desse levantamento, em 1990, em todos os estados, com relativo sucesso, faz com que, no Ministério da Educaçăo, se admita que esta experiência significa uma boa base para a constituição de um sistema de avaliação permanente e contínuo da educação pública brasileira.

Uma das conclusōes do estudo realizado é que, de maneira geral, năo se tem clareza sobre o produto da escola, sobre o trabalho por ela desenvolvido. Pergunta-se ao professor e ele nẩo tem conhecimento de quanto e como os alunos aprendem; também o diretor, da mesma forma, nảo está preocupado com os resultados que a escola obtém em termos de aprendizagem. 0 mesmo se pode afirmar em relaçăo à repetência e à produtividade. Isto nos leva a concluir pela ausência de informaçăo sobre a qualidade do ensino para aqueles que atuam $e$, principalmente, para aqueles que administram o sistema, que passam a programar, agir ou elaborar políticas baseado não se sabe em quê. Assim, talvez a maior vantagem deste Sistema Nacional de Avaliação seja a de gerar informaçōes e propiciar uma base para tomadas de decisōes nas administraçőes educacionais.

Além destes estudos no âmbito da escola, o sistema de avaliação também propōe estudos na esfera de gerência do sistema educacional, das administraçőes educacionais. Até o momento, foi desenvolvida uma metodologia de estudo de custos das administraçőes educacionais, que permite dimensionar quanto a máquina burocrática da administração consome para funcionar. Neste caso temos, então, vários indicadores da burocratização do sistema, do grau de centralização e de uma série de distorções que existem, hoje, no sistema educacional.

Finalizando, o Sistema Nacional de Avaliaçắo da Educaçăo Básica pretende, entäo, ser uma base para que outros trabalhos de avaliação sejam agregados, ampliando a discussåo sobre as condiçôes e os fatores que afetam a educaçảo no Brasil e para que o resultado destas discussóes seja incorporado, retorne para o sistema, de maneira que os agentes educacionais consigam implementar modificaçôes na prática pedagogica, na estruturaçäo do sistema educacional, etc.

A proposta do SAEB é a de que o sistema, no mínimo, ofereça rapidamente informações que năo sejam interiamente quantitativas, mas que indiquem aspectos da qualidade dos resultados que o sistema obtém para que, por um lado, o setor público tenha uma base melhor para decidir suas açőes e traçar sua políticas e, por outro, a sociedade tenha maiores informaçóes para estabelecer suas demandas por uma educação de qualidade. 